\title{
Nastavnička i studentska procjena u procesu definiranja i (pre)vrednovanja ishoda i sadržaja kolegija Analiza engleskih tekstova
}

\author{
Ivana Bašić \\ ibasicmobile@gmail.com \\ Filozofski fakultet Sveučilišta u Zagrebu \\ Marina Zubak Pivarski \\ marina.zubak.pivarski@gmail.com \\ Filozofski fakultet Sveučilišta u Zagrebu
}

\begin{abstract}
U radu se na temelju primjera iz prakse, konkretno kolegija Analiza engleskih tekstova u preddiplomskom studiju anglistike na Filozofskom fakultetu u Zagrebu, promišljaju načini kreiranja i (pre)vrednovanja ishoda i sadržaja kolegija u skladu sa zahtjevima suvremenih strateških ciljeva visokoga obrazovanja i suvremenih pristupa poučavanju. U prvom se dijelu rada potanko analizira nastavnička perspektiva u procesu definiranja ishoda navedenoga kolegija, njegove strukture, sadržaja i metoda poučavanja, nakon čega se predstavljaju rezultati ankete provedene među studentima koji su odslušali i položili kolegij s ciljem da nastavnici dobiju povratnu informaciju o studentskoj percepciji ostvarenja ishoda kolegija, primjerenosti sadržaja i metoda poučavanja te korisnosti kolegija za studij u cjelini i za buduće potrebe rada u struci. Zaključuje se da nastavnici u promišljanju ishoda vlastitih kolegija trebaju voditi računa da ti ishodi doprinose ishodima studijskoga programa u cjelini, da budu korisni studentima za budući rad u profesijama za koje se obrazuju i budu usklađeni sa strateškim dokumentima kojima se uređuje visoko obrazovanje na razini Republike Hrvatske i Europske unije. Osim toga, u proces kreiranja i vrednovanja kolegija treba aktivno uključiti studente jer njihova procjena služi kao korektiv
\end{abstract}


nastavnicima i istovremeno pomaže samim studentima da osvijeste ciljeve svojega obrazovanja i kompetencije potrebne za budući rad u profesijama za koje se obrazuju.

Ključne riječi: kompetencijski pristup visokom obrazovanju, nastavnička $i$ studentska procjena u (pre)vrednovanju kolegija, generičke i specifične kompetencije u preddiplomskom studiju anglistike.

\section{UVOD}

U ovom radu promišljaju se načini kreiranja i (pre)vrednovanja ishoda i sadržaja kolegija Analiza engleskih tekstova u preddiplomskom sveučilišnom studijskom programu anglistike na Filozofskom fakultetu Sveučilišta u Zagrebu. U prvom dijelu rada predstavlja se teorijski okvir na temelju kojega se raspravlja o problemu usklađivanja ishoda i sadržaja kolegija sa zahtjevima suvremenih obrazovnih strategija i potreba koje sveučilišni studiji trebaju zadovoljiti u današnjem svijetu te u skladu sa zahtjevima suvremenih pristupa poučavanju. U sljedećem dijelu rada govori se o nastavničkoj procjeni studentskih potreba, prosudbi njihovih ulaznih kompetencija i o motivaciji za uvođenje kolegija Analiza engleskih tekstova u studijski program anglistike. Objašnjava se na koji su način ishodi kolegija usklađeni s globalnim ishodima preddiplomskoga studijskog programa anglistike te kako doprinose kvalifikacijama za koje taj studij priprema studente. Potanko se raspravlja o procesu osmišljavanja ishoda kolegija te odabiru sadržaja i metoda primjerenih za ostvarenje tih ishoda. Nakon toga predstavljaju se rezultati izjašnjavanja studenata koji su odslušali kolegij te se na temelju tih rezultata raspravlja o usklađenosti nastavničke i studentske procjene prikladnosti strukture i sadržaja kolegija, učinkovitosti metoda poučavanja u ostvarenju predviđenih ishoda kolegija te korisnosti stečenih kompetencija za budući rad u struci. Konačno, donose se uopćeni zaključci i konkretne preporuke za učinkovito kreiranje ishoda kolegija.

\section{KOMPETENCIJSKI PRISTUP TERCIJARNOM OBRAZOVANJU I POUČAVANJE USMJERENO NA STUDENTE}

Kad je 2001. godine Republika Hrvatska potpisala Bolonjsku deklaraciju, dokument iz 1999. godine koji se odnosi na reformu sustava visokoga obrazovanja u Europi, tim je činom postala dijelom tzv. bolonjskog procesa, odnosno preuzela obvezu reformiranja hrvatskoga visokoobrazovnog sustava prema načelima kojima se uvode usporedivi kriteriji i metodologije planiranja i izvedbe visokoga obrazovanja na prostoru Europske unije (više 
o bolonjskom procesu vidi na https://www.azvo.hr/hr/visoko-obrazovanje/ bolonjski-proces). Prema Vlahović-Štetić i Kamenov (2016: 11), jedno od osnovnih načela prihvaćenih na razini Europske unije u planiranju kurikula u visokoškolskom obrazovanju jest kompetencijski pristup. Drugim riječima, studijski programi trebaju biti planirani i jezično izraženi tako da se jasno iskazuje koje će kompetencije student steći tijekom pojedine razine studija (preddiplomskog, diplomskog ili poslijediplomskog). Ideja profesionalnih kompetencija do kojih bi trebali voditi europski studijski programi razrađena je u okviru projekta Tuning (punim nazivom Tuning Educational Structures in Europe), započetoga 2000. godine s osnovnim ciljem određivanja glavnih smjernica prema kojima bi europske države trebale planirati i uskladiti nacionalne studijske programe, a da istovremeno mogu zadržati svoje lokalne različitosti proizašle iz vlastitoga iskustva. Tuning program tako predlaže ciljeve, rezultate, odnosno ishode kojima bi trebali težiti studijski programi na svakoj od triju razina visokoškolskoga obrazovanja, a svaki od tih ishoda zapravo predstavlja kompetencije koje bi studenti trebali steći na pojedinoj razini tercijarnoga obrazovanja. U kontekstu visokoga obrazovanja kompetencije se obično dijele na generičke i područno specifične, a predstavljaju spoj znanja, vještina i vrijednosti koje je pojedinac stekao i razvio tijekom studija (Tuning, 2008; Vlahović Štetić i Kamenov, 2016). Nadalje, ishodi pojedinih studijskih programa trebaju biti usklađeni s kvalifikacijama za koje taj studijski program studenta osposobljava, odnosno iz formulacije ishoda studijskih programa treba biti jasno što će završeni student pojedinoga studija moći raditi. S ciljem da se olakša usporedivost i prenosivost visokoobrazovnih kvalifikacija na razini Europske unije, 2008. godine uspostavljen je Europski kvalifikacijski okvir (vidi https://europa. eu/europass/en/european-qualifications-framework-eqf), koji je usklađen s Kvalifikacijskim okvirom za europski prostor visokoga obrazovanja (2005). Kao dio tog okvira razrađeni su kriteriji, tj. opisi ishoda učenja na svim razinama visokoga obrazovanja, tzv. Dublinski deskriptori (2005). Države članice, pa tako i Republika Hrvatska, nastoje ažurirati i uskladiti nacionalne kvalifikacijske okvire (u slučaju RH, Hrvatski kvalifikacijski okvir, HKO, vidi www.kvalifikacije.hr) s navedenim strateškim europskim dokumentima kako bi svojim stručnjacima omogućile mobilnost na tržištu rada, a istovremeno potencijalnim studentima i poslodavcima dale jasan uvid $u$ kvalifikacije koje se stječu diplomom na pojedinom studijskom programu.

Od uvođenja bolonjskoga procesa na Filozofskom fakultetu Sveučilišta u Zagrebu u osmišljavanju studijskih programa i silaba pojedinih kolegija nastoji se primjenjivati kompetencijski pristup, a zahtjev za jasnim koncipi- 
ranjem općenitih ishoda pojedinoga studijskog programa i usklađivanjem ishoda pojedinih kolegija sa zajedničkim ishodima bio je postavljen kao temelj za promišljanje cjelovite reforme studijskih programa koja je na tom fakultetu započela 2018. godine. U revidiranju svojih postojećih studijskih programa na Odsjeku za anglistiku nastojali smo objediniti vlastitu tradiciju i dobre prakse poučavanja sa suvremenim spoznajama i današnjim potrebama studenata. Pritom smo se vodili načelom poučavanja usmjerenoga na studente (eng. student-centered learning), koje se i tradicionalno njegovalo u većem broju kolegija u studijskom programu anglistike, a danas se smatra nezaobilaznim u postizanju kvalitete poučavanja u visokom obrazovanju, o čemu svjedoče i strateški dokumenti europskoga visokoobrazovnog područja (London Communiqué 2007, Leuven Communiqué 2009, Standards and Guidelines for Quality Assurance in the European Higher Education Area (ESG) 2015). Naime, studente uključujemo u sve faze osmišljavanja i vrednovanja kolegija, što ima dva komplementarna cilja - studente dodatno motivira da aktivno promišljaju o kompetencijama koje su im potrebne za napredak u studiju i budući profesionalni rad te o učinkovitim načinima postizanja tih kompetencija, a nastavnicima služi kao polazišna osnova za kreiranje i dorađivanje ishoda i silaba kolegija. Dakle, studentska procjena postaje jedan od ključnih elemenata u postupku konstruktivnoga poravnanja (Vlahović Štetić i Kamenov 2016, prema Biggs i Tang 2007), odnosno usklađivanja ishoda kolegija sa sadržajima i aktivnostima koje se potiču tijekom poučavanja te s onim što će se vrednovati u kolegiju.

\section{NASTAVNIČKA PERSPEKTIVA U KREIRANJU ISHODA, SADRŽAJA I METODA POUČAVANJA U KOLEGIJU ANALIZA ENGLESKIH TEKSTOVA}

\subsection{Ishodi kolegija Analiza engleskih tekstova}

Kolegij Analiza engleskih tekstova obavezan je kolegij za sve studente anglistike u drugoj godini, točnije četvrtom semestru preddiplomskoga studija engleskog jezika i književnosti na Filozofskom fakultetu u Zagrebu. Zamišljen je kao nadogradnja kompetencija stečenih u temeljnim jezičnim kolegijima Suvremeni engleski jezik 1, 2 i 3, koje studenti slušaju u prva tri semestra studija. Svrha je tih triju kolegija pripremiti studente za samostalan stručni rad u studiju filologije kao i cjeloživotno usavršavanje komunikacijske i kulturološke kompetencije u engleskom jeziku. Ishodi kolegija Analiza engleskih tekstova rezultat su temeljitoga promišljanja potreba stu- 
denata anglistike s obzirom na njihove ulazne i izlazne kompetencije, odnosno predznanja s kojima dolaze na studij, kompetencija koje moraju steći do diplome na preddiplomskom studiju te vještina potrebnih za nastavak studija. Naime, po završetku preddiplomskoga studija anglistike studenti stječu kvalifikacije za samostalan rad u temeljnoj anglističkoj struci, dok se tek završetkom diplomskoga studija kvalificiraju za specifična zanimanja u toj struci (nastavnik engleskoga jezika, prevoditelj engleskoga jezika i stručnjak za engleski jezik, književnost i kulturu). Stoga je naglasak u čitavom preddiplomskom studiju anglistike na usvajanju generičkih kompetencija koje studentima omogućuju samostalan akademski rad te na područno specifičnim kompetencijama koje se prvenstveno tiču visoke komunikacijske i kulturološke kompetencije u engleskome jeziku te osposobljavanja za samostalno lingvističko i književno-kulturološko proučavanje teksta.

Pri formulaciji ishoda kolegija uzimali smo u obzir načelne stručne preporuke, vodeći računa da ishodi budu formulirani konkretno, jasno i specifično, u obliku kompetencija koje će student moći pokazati, a nastavnik izmjeriti i ocijeniti (vidi Vlahović-Štetić i Kamenov, 2016: 15). Pritom smo se vodili Bloomovom taksonomijom ishoda obrazovanja (Anderson i Krathwohl, 2001), koja opisuje različite stupnjeve znanja, vještina i odnosa prema učenju te daje primjere mjerljivih ishoda učenja na svakoj razini. Konačno, ishode smo definirali prema kompetencijama koje su Dublinskim deskriptorima (pro)pisane za preddiplomsku razinu studija, vodeći računa o primjerenoj zastupljenosti generičkih i strukovno specifičnih kompetencija te o mjestu kolegija u hodogramu preddiplomskoga studija anglistike. Promotrit ćemo ishode kolegija i objasniti rezon kojim smo se vodili u njihovom definiranju te sadržaje i metode koje smo odabrali za učinkovitije ostvarenje tih ishoda.

Nakon odslušanoga i položenoga kolegija Analiza engleskih tekstova student(ica) će moći:

1. Uočiti organizaciju tekstova različite složenosti na engleskom jeziku, dijelove cjeline i njihove međusobne logičke odnose.

2. Razlikovati važne od manje važnih dijelova pročitanoga teksta u tekstovima različitih razina složenosti na engleskom jeziku, tj. raščlaniti tekst tako da se utvrdi koje su glavne ideje i informacije, a koje popratne.

3. Jezično preoblikovati (parafrazirati) dijelove pročitanoga teksta tako da budu gramatički, stilski i komunikacijski prihvatljivi.

4. Sažeti i protumačiti smisao pročitanih tekstova na engleskom jeziku koji pripadaju različitim tipovima diskursa i različitim funkcionalnim stilovima. 
5. Samostalno istražiti i utemeljeno komentirati kulturne, društvene i povijesne elemente pojedinih kultura engleskoga govornog područja koji se pojavljuju u tekstu.

6. Na temelju konteksta uporabe informacija u tekstu prepoznati sve razine značenja koje se tekstom komuniciraju i kritički procijeniti njihove moguće komunikacijske učinke.

7. Isplanirati strukturu vlastita pisanoga teksta i napisati akademski argumentacijski tekst na engleskom jeziku prema uzusima akademskoga diskursa, vodeći računa o etičkoj i društvenoj odgovornosti.

Svi su od ovih ishoda povezani s generičkim kompetencijama, odnosno vještinama komunikacije i učenja, zaključivanja i rasuđivanja, znanja i razumijevanja te primjene znanja i razumijevanja. Te su kompetencije generičke u smislu da ih je potrebno razvijati u svakom studiju, a u ovom su kolegiju specifične utoliko što su ovdje povezane s konkretnim područjem studija engleskoga jezika i književnosti i vještinama potrebnima za uspješan studij u tom području, prvenstveno s visokim stupnjem komunikacijske kompetencije na engleskome jeziku i poznavanjem anglofonih kultura. Nadalje, neki od navedenih ishoda dovoljno su široko definirani da ih se može smatrati i globalnim ishodima preddiplomskoga studija anglistike čijem ostvarenju u određenoj mjeri pridonose i neki drugi kolegiji u preddiplomskome studiju. Takva su preklapanja u filološkome studiju očekivana i potrebna jer se radi o razvoju kompetencija koje je potrebno kontinuirano nadograđivati.

\subsection{Sadržaji i metode poučavanja u kolegiju Analiza engleskih tekstova}

U definiranju navedenih ishoda od presudne je važnosti bilo neposredno dugogodišnje nastavničko iskustvo na temelju kojega smo uočili i izdvojili najvažnije probleme s kojima se studenti suočavaju pri čitanju i razumijevanju različitih vrsta tekstova. Naime, u trenutku upisa na studij anglistike hrvatski studenti, bez obzira na njihov relativno visok stupanj jezične kompetencije u engleskome jeziku (visoka B2 razina prema ZEROJ-u (2005)), često nemaju dovoljno razvijenu čitalačku pismenost koja im je potrebna da bi mogli dubinski razumjeti i kritički vrednovati tekstove s kojima se susreću u studiju. Kad studenti pokušaju prepričati pročitani tekst, često primjećujemo da, najjednostavnije rečeno, ne znaju uočiti što je bitno, a zanemariti što je manje bitno pa se u prepričavanju često zapliću i gube u detaljima i ne mogu izdvojiti nosive elemente teksta. Pritom je jasno da to nije problem jezičnoga izražavanja kao takvog, nego prvenstveno problem dubinskoga razumijevanja pročitanoga teksta, tj. čitalačke pismenosti. 
Čitalačka pismenost jedna je od temeljnih složenih generičkih kompetencija koje današnji obrazovni kurikuli prepoznaju kao preduvjet za cjeloživotno učenje i kao „most kojim se spaja odnos prema sebi i drugima“, odnosno uspostavlja "okvir za razumijevanje sebe i drugoga kroz tekstove“ (Peti-Stantić, 2019: 120-121). Čitalačka pismenost razvija se korištenjem kombinacije različitih metoda i strategija, od kojih je prva aktivan rad na produbljivanju i proširivanju vokabulara, nakon čega slijedi razvijanje sposobnosti prepoznavanja strukture različitih vrsta tekstova (Peti-Stantić, 2019: 132). Sljedeći je korak prema aktivnom razvijanju čitalačke pismenosti pokušaj sinteze, tj. sažimanja pročitanoga teksta. Sažimanje je prepoznato kao „jedna od najučinkovitijih strategija čitanja i učenja“ jer „osim usmjeravanja na važne informacije $u$ tekstu potiče i nadgledanje vlastitog razumijevanja" (Kolić-Vehovec, 2013). Naime, sažimanje od čitatelja zahtijeva aktiviranje različitih razina znanja, povezivanje informacija u tekstu s vlastitim prethodnim znanjem te aktivnu uporabu jezika u preformuliranju i parafraziranju ideja i iskaza iz izvornoga teksta. Osim toga, u akademskom je kontekstu razlikovanje između parafraziranja i izravnoga citiranja posebno važno i zbog etičke dimenzije, odnosno učenja o nužnosti navođenja izvora i izbjegavanja plagiranja. Zbog svega navedenoga, sažimanje pročitanih tekstova u kolegiju Analiza engleskih tekstova prepoznato je kao vježba kojoj treba posvetiti posebnu pažnju. Iako se zapravo radi o generičkoj vještini koja je preduvjet za samostalno učenje, naše iskustvo pokazuje da velika većina studenata tom vještinom ne ovlada u odgovarajućoj mjeri u prethodnom obrazovanju pa se taj nedostatak svakako treba ispraviti u ranoj fazi studija. Nadalje, u studiju engleskoga jezika vještine parafraziranja i sažimanja pročitanih tekstova na engleskome jeziku nisu samo generičke nego su i područno specifične vještine jer se pomoću njih razvija i nadograđuju i jezična i kulturološka kompetencija, što ih čini višestruko vrijednima poučavanja.

S obzirom da su dubinsko čitanje i analiza teksta složeni procesi koji se odvijaju u fazama, da bismo studente uspješno vodili kroz te procese i osigurali postupnu progresiju u ostvarenju ishoda kolegija, osmislili smo sljedeće faze i metode poučavanja. Svaki tekst na kojem se radi u kolegiju najprije se detaljno obradi u smislu vokabulara, kulturoloških referenci i pojmova koji se pojavljuju u tekstu. Intenzivan rad na vokabularu i kulturološkim referencama nije odlika samo ovoga kolegija, nego je jedno od općih mjesta u različitim kolegijima u filološkom studiju. Naime, kao i jezična kompetencija u užem smislu, kulturološka kompetencija kontinuirano se razvija i nadograđuje, a preddiplomski studij treba osposobiti studente za samosta- 
lan rad i cjeloživotno učenje u filološkoj struci. Kao i u prethodnim temeljnim jezičnim kolegijima na koje se Analiza engleskih tekstova nastavlja, studenti dobivaju ciljane zadatke za rad na vokabularu, koje trebaju riješiti koristeći se prikladnim alatima, uglavnom rječnicima i elektroničkim korpusima. Zadaci uključuju vježbe sa sinonimima, antonimima, polisemijom i homonimijom, kolokacijama, frazeologijom, parafrazom, uporabom riječi u različitim kontekstima, funkcionalnim stilovima i registrima. Vježbama vokabulara osvješćuju se procesi izgradnje značenja u jeziku, pri čemu se na konkretnim primjerima kontinuirano upućuje na neodvojivost i spregu leksika, gramatike i pragmatike u tome procesu. Raspravlja se o namjeni teksta i njegovoj ciljnoj publici, kako bi se osvijestila potreba sagledavanja komunikacijskoga procesa u širem društvenom kontekstu, što je ključno za razvoj komunikacijske kompetencije. Slijedi analiza strukture teksta, nakon čega se utvrđuju i parafraziraju glavna ideja teksta, glavne ideje u svakom odlomku, zaključak teksta te se tako izdvojeni nosivi elementi teksta spajaju u tekst sažetka koristeći se primjerenim veznim sredstvima kako bi se postigla koherentnost na razini čitavoga teksta.

Što se tiče načina izvedbe nastave i metoda poučavanja, kolegij je koncipiran kao kombinacija seminara i vježbi, a u nastavi se radi i individualno i u skupinama, kako bi studenti u svakoj fazi učenja međusobno usporedili vlastite uratke, raspravili o tome što je bitna i neizostavna informacija $u$ tekstu, a što su dodatne informacije i detalji kojima se pojačava argumentacija ili ilustrira neki problem. Pisanje sažetaka pročitanoga teksta u kolegiju jasno je vođeno kroz pojedine korake (dubinsko čitanje, analiza, parafraza, sinteza). Osim toga, studenti na temelju jasnih kriterija (oblikovanih kao pitanja u upitniku koji se koristi prilikom vrednovanja sažetaka) čitaju, vrednuju i komentiraju tekstove svojih kolega, kako bi iz pozicije čitatelja osvijestili što sve olakšava ili otežava razumijevanje teksta. Studenti ovaj zadatak ponovo rade i individualno i u skupinama, pri čemu uspoređuju svoje procjene pojedinih tekstova s procjenama kolega. Takva vježba studentima olakšava čitanje tuđih i sastavljanje vlastitih tekstova te ih jasno upućuje na to kako treba oblikovati tekst sažetka i što će se vrednovati u zadatku sastavljanja sažetka pročitanoga teksta, koji je jedan od završnih elemenata vrednovanja uspješnoga ostvarenja ishoda kolegija.

Nakon što ovladaju vještinama parafraziranja i sažimanja tekstova, smatra se da su studenti stekli preduvjete za rad na samostalnoj produkciji akademskoga teksta. Kako bi uspješno ostvarili sedmi ishod kolegija, studente se ciljano upućuje u osnovne vještine akademskoga pisanja potrebne za pisanje argumentacijskoga eseja te ih se vodi i usmjerava u pojedinačnim 
koracima u tome zadatku (pretraživanje relevantnih izvora, citiranje, planiranje i organizacija teksta, kratak nacrt teksta, razrada teksta, prva verzija, revidiranje teksta, konačna verzija eseja). U svakome od navedenih koraka studenti od nastavnika dobivaju povratnu informaciju i revidiraju tekst sukladno uputama koje su dobili. U tom procesu uče kritički vrednovati, citirati i parafrazirati tuđe te oblikovati vlastite ideje, kao i primati i prihvaćati konstruktivnu kritiku vlastitoga rada, što su temeljne generičke akademske kompetencije. Istovremeno aktivno rade na izgradnji vlastite komunikacijske kompetencije $\mathrm{u}$ akademskom engleskom jeziku. Pritom konkretnu temu i naslov eseja studenti biraju sami, ali tema mora biti povezana s problemima o kojima se raspravljalo na temelju tekstova koje smo zajednički čitali i analizirali u kolegiju.

Kako bi se omogućio rad na kvalitetnim tekstovima i povećala studentska motivacija, što je jedan od osnovnih preduvjeta za aktivniji studentski angažman, bolju usvojenost sadržaja i ovladavanje predviđenim kompetencijama, u kolegiju Analiza engleskih tekstova osnovni radni materijal je čitanka koju sastavljamo vodeći računa o potrebama i studenata, ishodima kolegija i ishodima čitavoga studijskog programa anglistike. Čitanka sadrži niz tematski okupljenih tekstova različitih žanrova. Teme su uvijek aktualne i društveno relevantne, kako bi se studente potaklo da se aktivno uključe u diskusiju i povezuju tekstove s vlastitim iskustvom. U dvjema akademskim godinama koje su obuhvaćene istraživanjem studentske percepcije ishoda kolegija koje ćemo prikazati u sljedećem dijelu rada zajednička tema tekstova u čitanci bila je nove digitalne tehnologije i njihov utjecaj na ljudske kognitivne procese, usvajanje znanja, čitanje s razumijevanjem i način poimanja svijeta. Ova je tema odabrana kao poticajna za raspravu upravo zbog toga što se kolegij bavi dubinskim čitanjem i analizom tekstova, za što je potrebno vrijeme, usmjerena pažnja i koncentracija, a upravo nove tehnologije potiču na usvajanje novih navika brzoga i površnoga čitanja kraćih fragmentiranih tekstova te često utječu na smanjenje pažnje i smanjenu koncentraciju prilikom čitanja duljih i zahtjevnijih tekstova.

Zaključno, u odabiru načina poučavanja i metoda prikladnih za ostvarenje ishoda kolegija vodili smo se načelima postupnosti i primjerenosti. Bilo nam je bitno da studenti u svakom trenutku znaju što i zašto rade te kako će ih koji korak dovesti do ostvarenja pojedinoga cilja. Jesmo li u tome uspjeli i u kojoj se mjeri naša procjena podudara sa studentskom percepcijom ostvarenja ishoda kolegija, primjerenosti sadržaja i metoda korištenih u nastavi za ostvarenje zadanih ishoda te korisnosti ishoda kolegija za potrebe studija i rada u struci prikazat ćemo u sljedećem dijelu rada. 


\section{STUDENTSKA PROCJENA ISHODA, SADRŽAJA I METODA POUČAVANJA U KOLEGIJU ANALIZA ENGLESKIH TEKSTOVA}

$\mathrm{U}$ ovom dijelu rada prikazat ćemo rezultate studentske procjene ishoda i strukture kolegija koja je provedena pomoću ankete koju su studenti ispunjavali na kraju semestra, nakon odslušanoga kolegija Analiza engleskih tekstova. Osnovni način provjere ostvarenja ishoda u ovom kolegiju je kontinuirano praćenje napretka studenata putem kolokvija, koji prvenstveno obuhvaćaju pisanje sažetka i eseja. Međutim, rezultati kolokvija ne govore nam mnogo o tome jesu li studenti osvijestili ciljeve i svrhu kolegija te percipiraju li kolegij korisnim. Stoga smo nakon što su studenti odslušali i položili kolegij odlučili anonimnom anketom provjeriti kako studenti procjenjuju ostvarenost ishoda kolegija i primjerenost sadržaja i metoda korištenih u nastavi, vide li na koji su način ti ishodi povezani s ostalim kolegijima i općenitim ishodima studija te konačno, smatraju li kompetencije koje su stekli u ovom kolegiju relevantnima za svoje buduće zanimanje. Osnovni cilj provođenja ankete bio je da kao nastavnici dobijemo dodatne podatke za procjenjivanje koncepcije kolegija na temelju kojih ćemo moći napraviti izmjene i dorade koje procijenimo potrebnima. Dodatni je cilj bio da potaknemo studente da i sami osvijeste sustav, pojedine korake i krajnje ciljeve svojega obrazovanja te nastavnicima sugeriraju što bi pomoglo da proces učenja bude učinkovitiji. Naime, pri upisu u kolegij Analiza engleskih tekstova studenti su kao sastavni dio silaba dobili jasno istaknute ishode kolegija, a tijekom nastavnoga procesa redovno im se objašnjavalo koji su ishodi pojedine nastavne jedinice te što bi trebao biti rezultat pojedine faze procesa učenja. Kada su nakon odslušanoga i položenoga kolegija zamoljeni da ispune anketu, dobili su priliku da aktivno procijene je li ono što je najavljeno zaista $\mathrm{i}$ ispunjeno te da sami sebi osvijeste u kojoj su mjeri i na koje načine profitirali od kolegija te kako će im stečena znanja i vještine koristiti u budućem radu, tijekom studija i kasnije.

\subsection{Ispitanici i instrument}

Istraživanje je provedeno $\mathrm{u}$ dvjema uzastopnim akademskim godinama, 2018./2019. i 2019./2020., a sudjelovalo je ukupno 77 ispitanika, studenata druge godine preddiplomskog studija Engleskog jezika i književnosti na Filozofskom fakultetu u Zagrebu koji su ispunili anketu neposredno nakon što su odslušali navedeni kolegij. Anketa je bila dobrovoljna i anonimna. Postavljena je na sučelje za učenje na daljinu Omega koje se koristi u nastavi i studenti su zamoljeni da je ispune. U akademskoj godini 2018./2019. 
anketu je ispunilo 65 studenata, a u akademskoj godini 2019./2020. znatno manji broj, svega 12 studenata. Razlika u broju studenata koji su ispunili anketu u dvjema akademskim godinama proizlazi iz činjenice da je u akademskoj godini 2019./2020. zbog pandemije koronavirusa u ožujku bila uvedena iznenadna karantena te je nastava u ljetnom semestru održana na daljinu, putem platforme Omega i alata Big Blue Button. U takvim okolnostima nastava je morala doživjeti određene promjene, pri čemu su i neke metode rada bile prilagođene novonastalim prilikama, ali planirani ishodi kolegija bili su ostvareni. Zbog novonastalih okolnosti i odaziv studenata bio je slabiji nego u godini prije, kad su nastavnici u nastavi uživo mogli lakše potaknuti studente da se dodatno angažiraju i ispune anketu. Unatoč slabijem odazivu, analiza odgovora pokazala je da se studentske procjene u obje godine ne razlikuju značajno u kvalitativnom smislu, zbog čega smo odlučili u prikazu rezultata objediniti ankete iz obiju akademskih godina. Sveukupno je u obje godine u anketi dobrovoljno sudjelovalo preko $40 \%$ od ukupnoga broja studenata (190), uzimajući u obzir da je u svakoj akademskoj godini ovaj kolegij polazilo i uspješno završilo 95 studenata.

Anketa koju su studenti ispunjavali sastojala se od 9 pitanja. Ispitanici su na pojedina pitanja trebali odgovoriti odabirom ocjene na ljestvici od pet stupnjeva, pri čemu ocjene nisu bile izražene numerički nego opisno, kao što se može vidjeti u nastavku. Na neka su pitanja ispitanici trebali odgovarati potvrdno ili niječno. Osim toga, ispitanici su imali mogućnost obrazložiti svoj odgovor na svako pitanje.

Anketa se tematski može podijeliti u dva dijela. Prvih šest pitanja tiču se sadržaja kolegija Analiza engleskih tekstova, njihove primjerenosti u ostvarenju ishoda kolegija te jasnoće strukture kolegija i metoda poučavanja. $\mathrm{Na}$ neka od ovih pitanja studenti su odgovarali samo potvrdno ili niječno, dok su na druga odgovarali odabirom ponuđenih odgovora na ljestvici od pet stupnjeva. U drugom dijelu ankete postavili smo tri pitanja koja su se ticala procjene uklopljenosti kolegija u opću shemu i ishode preddiplomskoga studijskog programa, konkretno predznanja potrebnih za praćenje kolegija te korisnosti i relevantnosti kolegija. Rezultate studentskoga vrednovanja prikazujemo u nastavku.

\subsection{Rezultati anketa i rasprava}

Odgovori na prvo pitanje o zadovoljstvu sadržajem kolegija prikazani su u Tablici 1. Ispitanici su se u najvećoj mjeri opredijelili za ocjenu vrlo zadovoljan (32 studenata), a čak 20 studenata je bilo izuzetno zadovoljno, dok 
je 22 ispitanika bilo zadovoljno. Tek 3 ispitanika opredijelilo se za ocjenu nedovoljno zadovoljan, a nitko se nije izjasnio kao nezadovoljan.

Tablica 1. Jeste li zadovoljni sadržajem kolegija (obrada tekstova, analiza tekstova, sinteza, istraživanje i esej)?

\begin{tabular}{|l|l|l|l|l|}
\hline Izuzetno zadovoljan & vrlo zadovoljan & zadovoljan & nedovoljno zadovoljan & nezadovoljan \\
\hline $20(25 \%)$ & $32(42 \%)$ & $22(29 \%)$ & $3(4 \%)$ & - \\
\hline
\end{tabular}

Samo troje ispitanika izrazilo je svoje nedovoljno zadovoljstvo sadržajem kolegija obrazlažući ${ }^{1}$ :

- u kolegiju se obrađuje puno različitih tema u kojima sam se izgubila

- mislila sam da ćemo se fokusirati na različite vrste tekstova (i književne, na primjer)

- preveliki je fokus bio na eseju i trebalo se više koncentrirati na zadatke za 2. kolokvij

- zadovoljna sam sa svime osim pisanjem sažetaka; smatram da pisanje sažetaka nije od neke koristi niti za naš studij niti za budući posao

Ipak, većina je izrazila svoje zadovoljstvo sadržajem kolegija. Ovdje su samo neki od komentara, odabrani na način da se izbjegne ponavljanje odgovora i da se omogući uvid u raspon različitih odgovora:

- kolegij je bio vrlo dobro organiziran te su teme koje razrađuje vrlo važne u sferi lingvista; bilo je interesantno vidjeti različita stajališta kroz tekstove koje smo obrađivali

- zadovoljan sam sadržajem kolegija jer mi je skrenuo pozornost na različite tehnike oblikovanja tekstova i kontekste u kojima se tekstovi upotrebljavaju, s čime prethodno nisam bio upoznat

- jasno, puno važnih informacija, korisno, trening mozga, logičko slaganje teksta

- korisno za pisanje radova i pristup tekstu koji ne poznajemo; razvija kritički pristup tekstu

- smatram da su tekstovi koji se obrađuju zanimljivi, relevantni što se tiče vokabulara i generalno korisni za analizu; dobro je što se uči pisati sažetak i esej

- tekstovi su se temeljito analizirali i različitim zadacima smo dobili odličnu pripremu za esej

- super je što je bilo različitih vrsta tekstova (recepcija i produkcija) i grupnih radova

- dublja implementacija dosadašnjih kompetencija stečenih u ranijim kolegijima

- nastava se odvija na drugačiji način te mi se to sviđa; puno komentiramo i koristimo se jezikom (usmeno i pismeno)

Drugim pitanjem, prikazanim u Tablici 2., saznali smo u kojoj mjeri ispitanici smatraju temu tekstova iz čitanke zanimljivom kao polazište za

\footnotetext{
${ }^{1}$ Slijede navodi studenata te stoga nisu lektorirani.
} 
čitanje i analizu tekstova. Čak 26 ispitanika ocijenilo je temu izuzetno zanimljivom, 36 ju je ocijenilo vrlo zanimljivom, a 13 ispitanika je smatralo da je tema zanimljiva. Tek jedan ispitanik smatra da je tema nedovoljno zanimljiva, a jedan, pak, da je tema posve nezanimljiva.

Tablica 2. Smatrate li temu tekstova iz čitanke (informacijska tehnologija i utjecaji) zanimljivom kao polazište za čitanje i analizu tekstova?

\begin{tabular}{|l|l|l|l|l|}
\hline izuzetno zanimljiva & vrlo zanimljiva & zanimljiva & nedovoljno zanimljiva & nezanimljiva \\
\hline $26(34 \%)$ & $36(47 \%)$ & $13(17 \%)$ & $1(1 \%)$ & $1(1 \%)$ \\
\hline
\end{tabular}

Većina ispitanika smatra da su teme aktualne i relevantne jer su povezane s problemima suvremenoga društva i bitne su za razumijevanje današnjice. Također, smatraju da su teme (posebice utjecaj interneta i društvenih mreža) bliske studentskom iskustvu te da idu ukorak s vremenom. Jedan ispitanik navodi da je tema aktualna i sagledana iz različitih kutova te da je posebno zahvalna za seminarski rad jer je dovoljno široka da svatko nađe nešto što ga dovoljno zanima. Nadalje, jedan ispitanik smatra da je u današnje vrijeme nemoguće zamisliti život bez tehnologije te je zato potrebno analizirati njezine učinke. Dodaje da je vrlo zanimljivo vidjeti kako se tehnologija udomaćila u našim životima te je pomalo zastrašujuće saznati više o njezinim lošim stranama. Samo jedan ispitanik iskazuje da ga tema pretjerano ne zanima jer je to tema o kojoj se svakodnevno raspravlja u medijima, no većina je ipak stava da je tema tekstova suvremena, da se s njom svi mogu poistovjetiti i da o njoj treba više govoriti.

Na treće pitanje, prikazano Tablicom 3., 76 studenata odgovorilo je da je struktura kolegija jasna, dok tek 1 student smatra da struktura kolegija nije jasna.

Tablica 3. Je li struktura kolegija jasna (sažeci, eseji)?

\begin{tabular}{|l|l|}
\hline DA & NE \\
\hline $76(99 \%)$ & $1(1 \%)$ \\
\hline
\end{tabular}

Jedan ispitanik smatra da struktura kolegija nije jasna, obrazlažući svoj odgovor komentarom da je „loše što smo pisali prvi kolokvij dok smo već duboko zagazili u sljedeću temu“. Ostali ispitanici smatraju da je kolegij jasno strukturiran, da je dovoljno vremena posvećeno uputama, te dodaju sljedeće:

- sve što je bilo izloženo na početku je održano/ispunjeno, bez iznenađenja

- sve je bilo jasno obrazloženo te nije bilo problema sa razradom materijala 
- smatram da je od početka kolegija bilo jasno da ćemo pisati sažetke različitih tekstova i da ćemo na kraju pisati esej, te zašto su vještine pisanja sažetaka i eseja važne

- jest, struktura kolegija je jasna; nije teško primijetiti što se traži od studenata

- precizno je određeno što se traži od studenata i kako se vrednuje

U četvrtom smo pitanju pitali ispitanike smatraju li da je pisanje sažetaka u kolegiju jasno vođeno kroz faze dubinskoga čitanja, analize pročitanoga, parafraze i naposljetku sinteze. Iz Tablice 4. jasno je da je čak 33 studenata smatralo postupak pisanja sažetaka izuzetno jasno vođenim, 27 ispitanika smatralo je da je postupak vrlo jasno vođen, a 14 ispitanika na ovo se pitanje izjasnilo ocjenom jasno vođen. Tek 3 ispitanika smatra da je pisanje sažetaka nedovoljno jasno vođeno.

Tablica 4. Smatrate li da je pisanje sažetaka jasno vođeno u kolegiju (dubinsko čitanje, analiza, parafraza, sinteza)?

\begin{tabular}{|l|l|l|l|l|}
\hline izuzetno jasno & vrlo jasno & jasno & nedovoljno jasno & nije jasno \\
\hline $33(43 \%)$ & $27(35 \%)$ & $14(18 \%)$ & $3(4 \%)$ & - \\
\hline
\end{tabular}

Svega jedan ispitanik odgovara da ne vidi korist sažetaka, ali ne obrazlaže svoj odgovor, a troje studenata u obrazloženjima navodi da smatra da treba više vremena posvetiti parafraziranju ili da treba bolje pojasniti što je dobar, a što loš sažetak. Ipak, kako je vidljivo iz Tablice 4., većina ispitanika smatra da je vođenje pisanja sažetaka bilo vrlo ili izuzetno jasno te $u$ svojim obrazloženjima ispitanici navode da su tehnika i način pisanja sažetaka jasno objašnjeni, da su imali mnogo prilika vježbati pisanje sažetaka u grupnom radu i samostalno te su uvijek dobili povratnu informaciju u najkraćem roku. Osim toga, imali su priliku vidjeti i sažetke svojih kolega te ih međusobno uspoređivati. Nadalje, studenti uviđaju da je uvijek važno znati prepoznati najvažnije komponente nekog teksta te ih parafrazirati. $\mathrm{Na}$ kraju, zaključuju da, ako se slijede upute, rezultat moraju biti dobri ili odlično napisani sažeci.

Nadalje, u petom pitanju zanimalo nas je smatraju li ispitanici da su koraci u razradi teme za pisanje eseja korisni (od traženja izvora, kratkog pregleda, koncepta, tj. prve verzije, revizije i konačne verzije eseja). U Tablici 5. prikazano je da čak 42 ispitanika smatra te korake izuzetno korisnima, 22 vrlo korisnima, a 12 korisnima. Tek 1 ispitanik smatra da su ti koraci nedovoljno korisni, dok ni jedan student ne smatra da ti koraci nisu korisni. 
Tablica 5. Smatrate li korake u razradi teme za pisanje eseja korisnima (traženje izvora, kratak pregled (outline), koncept (first draft), revizija, konačna verzija eseja)?

\begin{tabular}{|l|l|l|l|l|}
\hline izuzetno korisno & vrlo korisno & korisno & nedovoljno korisno & nije korisno \\
\hline $42(54,5 \%)$ & $22(29 \%)$ & $12(15,5 \%)$ & $1(1 \%)$ & - \\
\hline
\end{tabular}

Studenti su obrazložili svoje odgovore na sljedeći način:

- koraci u razradi teme čine mi se ekstremno korisnima, još više nego kod sažetaka, jer smo tim koracima uspjeli svesti nešto dosta teško i zahtjevno (pisanje eseja) na manje i relativno jednostavne korake

- olakšava nam pisanje eseja i daje smjer kad "ne znamo od kuda početi“

- ovaj esej mi je vjerojatno i najbolji koji sam ikad napisala upravo zato što smo se na nastavi posvetili svakom koraku u izradi eseja

- važni su za koherentnost eseja

- da, jer tako pišemo esej postepeno i s razumijevanjem i traženje izvora nam dodatno produbljuje znanje o temi o kojoj pišemo

- isprva nisam bila oduševljena idejom ovakvog pisanja eseja, ali mislim da se ovakav način rada na kraju ipak pokazao dosta korisnim. Bilo je zanimljivo vidjeti kako drugi studenti pristupaju istraživanju, organiziranju ideja i samom pisanju

- na ovakav način radimo postupno, a dobivamo povratnu informaciju za svaki korak

- vrlo korisno i rezultati se vide

- mislim da je ova struktura odlična i mogu je koristiti u svakoj situaciji koja bih zahtijevala pisanje istraživačkog rada

- izuzetno je korisno što nismo samo napisali i predali esej i mislim da se to vidi na rezultatima

Iako se većina ispitanika složila s time da je ovakvo vođenje kroz faze pisanja eseja korisna metoda te su mnogi zaključili da će primjenjivati ovakav pristup pri pisanju novih istraživačkih tekstova, nekoliko ispitanika smatra da im ovi koraci nisu potrebni jer nikada ne pišu kratak pregled teksta (outline), odnosno više vole „slobodnije“ korake. Neki su studenti zaključili da bi ovakav kolegij trebao biti ponuđen već na prvoj godini studija s obzirom da se već ranije, na književnim kolegijima, susreću sa zadacima pisanja seminarskih radova.

U zadnjem pitanju prvog dijela ankete, a prikazano u Tablici 6., 76 ispitanika odgovorilo je da smatra da ishodi kolegija doista proizlaze iz sadržaja kolegija (dubinsko čitanje i razumijevanje različitih tipova tekstova te sposobnost njihova sažimanja, produkcija novoga teksta temeljenoga na istraživačkom radu), a tek je 1 student odgovorio niječno. 
Tablica 6. Smatrate li da ishodi kolegija proizlaze iz sadržaja kolegija (dubinsko čitanje i razumijevanje različitih tipova teksta te sposobnost njihova sažimanja, produkcija novoga teksta temeljenoga na istraživačkom radu)?

\begin{tabular}{|l|l|}
\hline DA & NE \\
\hline $76(99 \%)$ & $1(1 \%)$ \\
\hline
\end{tabular}

Jedini student koji je odgovorio niječno čini se da nije razumio pitanje s obzirom da u njegovom obrazloženju stoji da se ishodi mogu postići neovisno o temi, a nas je zanimalo smatraju li studenti da su strukturni sadržaji kolegija (koji su bili navedeni u zagradi) usklađeni s ishodima kolegija. Uviđamo, međutim, vlastitu nespretnost $\mathrm{u}$ formulaciji pitanja, koja je mogla ispitanike zbuniti. Izdvajamo neka od obrazloženja koja su ispitanici dali za svoje odgovore:

- da, upravo kroz sadržaj kolegija se i sve nauči, pogotovo dobro razumjeti ideje u tekstu

- svakako, sadržaj kolegija nudi novi pogled na tekstove u cjelini, što naknadno može samo biti od pomoći u daljnjem bavljenju tekstovima na ostalim kolegijima ili u znanstvenom radu

- kolegij potiče dubinsko čitanje i razmišljanje o pročitanom

- osobito je korisno pisanje sažetaka, šteta je jedino što se to ne radi još u školama - sažetak i esej nam daju novi uvid u seciranje teksta i razlikovanje bitnog od nebitnog

U drugom dijelu ankete usredotočili smo se na percepciju studenata o uklopljenosti ovoga kolegija u preddiplomski studijski program anglistike te o važnosti ovoga kolegija za daljnji studij i budući rad. Tako smo postavljanjem sedmog pitanja, a što je prikazano u Tablici 7., htjeli saznati u kojoj mjeri studenti smatraju da su prethodni kolegiji jezičnih vježbi (Suvremeni engleski jezik 1, 2 i 3) potrebni za savladavanje ishoda definiranih u ovom kolegiju. 23 studenata smatra da su prethodni kolegiji potrebni, 23 smatra da su vrlo potrebni, a 26 da su izuzetno potrebni. Istovremeno, njih 3 smatra da ti kolegiji nisu previše potrebni, a 2 da su nepotrebni.

Tablica 7. U kojoj mjeri su prethodni kolegiji jezičnih vježbi potrebni za savladavanje ishoda definiranih u ovom kolegiju (iz pitanja 6)?

\begin{tabular}{|l|l|l|l|l|}
\hline izuzetno potrebni & vrlo potrebni & potrebni & nisu previše potrebni & nepotrebni \\
\hline $26(34 \%)$ & $23(30 \%)$ & $23(30 \%)$ & $3(4 \%)$ & $2(2 \%)$ \\
\hline
\end{tabular}

Ispitanici su u svojim obrazloženjima većinom izrazili kako smatraju da su prethodni kolegiji jezičnih vježbi vrlo ili izuzetno potrebni. 
- smatram da su Suvremeni engleski jezik 1, 2 i 3 temelj za svaki kolegij na studiju i korisni su za usvajanje ostalih kolegija od Sintakse do raznih književnih kolegija

- bitno je znati izraziti se pravim riječima, a to smo mogli savladati tokom prošla tri semestra; saznali smo kako radi unutarnji mehanizam jezika te njegova struktura te što je bitno objasniti, a što ne

- smatram da je vrlo teško napisati dobar esej ili sažetak ako nije usvojen dovoljan stupanj znanja jezika; također, osobno smatram da je dublje razumijevanje teksta nemoguće ako vokabular čitatelja nije dovoljno razvijen

- smatram da je dobro poznavanje jezika, te pogotovo jezičnih struktura bitno za dubinsko čitanje i produkciju vlastitog teksta

- bitno je poznavati pravilno koristiti jezik kako bi bilo moguće napisati kvalitetan tekst

- da nismo imali prethodno znanje, tko zna kako bi izgledali sažeci i eseji s obzirom na upotrebu vremena, veznih riječi, itd.

- prošli smo od riječi i rečenica do cijelih tekstova

Svega je troje ispitanika koji smatraju da prethodni kolegiji nisu previše potrebni za savladavanje ovoga kolegija obrazložilo svoje odgovore.

- mislim da su prethodni kolegiji potrebni, ali ne previše jer je ovaj kolegij drugačije koncipiran

- mislim da se može pohađati ovaj kolegij bez znanja npr. o vrstama riječi i funkciji rečeničnih elemenata

- vjerujem da sva gramatika koju smo u detalje učili na jezičnim vježbama nije pretjerano esencijalna pri savladavanju ishoda ovog kolegija budući da su to dva vrlo različita predmeta, jedan se fokusira na analiziranje tekstova, a drugi na gramatiku; mislim da bi ovaj predmet bio jednake težine bez obzira na kojoj godini studija bio.

U Tablici 8. prikazano je da 25 ispitanika na osmo pitanje odgovara da je kolegij izuzetno potreban za njihov studij, čak 36 smatra da je kolegij vrlo potreban za studij, dok je 12 ispitanika izrazilo da je ovaj kolegij potreban za njihov studij. Nasuprot tome, 4 studenata smatra da kolegij nije previše potreban za njihov studij.

Tablica 8. U kojoj mjeri smatrate da je kolegij koristan za vaš studij?

\begin{tabular}{|l|l|l|l|l|}
\hline izuzetno potreban & vrlo potreban & Potreban & Ne previše potreban & nepotreban \\
\hline $25(32,5 \%)$ & $36(47 \%)$ & $12(15,5 \%)$ & $4(5 \%)$ & - \\
\hline
\end{tabular}

Neki od komentara studenata koji smatraju kolegij vrlo i izuzetno potrebnim su navedeni:

- na obje studijske grupe nam je potrebna vještina pisanja i istraživanja

- pisanje sažetaka, istraživanje i pisanje eseja pojavljuje se u gotovo svakom kolegiju

- naš studij se zasniva na analizi, razumijevanju i pisanju tekstova (eseja, seminarskih i diplomskih radova) 
- kolegij je izuzetno bitan za stvaranje podloge za ispravno pisanje eseja, što je korisno za mnoge buduće kolegije, za seminarske i kasnije završne radove

- sintetizira gradivo jezičnih vježbi 1,2 i 3

- bitno je znati dubinski ući u tekst, ali i prezentirati njegovu esenciju, tj. najbitnije dijelove

- kolegij razvija dubinsko čitanje, što je osnovna intelektualna vještina; kolegij obrađuje zadatke koji se ne mogu obaviti automatizmom, već razmišljanjem u dubinu, stvaranjem mentalne slike

- tehnika dubinskog čitanja i različiti stadiji oblikovanja eseja mogu samo dodatno pomoći u daljnjem studiju, zbog čega bi rad na ostalim književnim kolegijima mogao postati znatno lakši i polučiti bolje ocjene

- kolegij nas potiče da tekstovima pristupamo kritičnije i detaljnije

- potreban je jer inače ne radimo dovoljno na pisanju

- korisniji mi je bio ovaj kolegij za pisanje tekstova nego književni kolegij i uvodi u književnost

- mislim da je iznimno koristan, ali bi bilo super da je na 1. godini jer smo saznali da krivo pišemo eseje čitavo ovo vrijeme

Postoji svega dva komentara ispitanika koji su smatrali da ovaj kolegij nije previše potreban:

- mislim da se mogu i druge korisnije stvari ukomponirati u kolegij

- iskreno, ne čini mi se da sam usvojila puno novih informacija o pisanju eseja; ovaj je bio istraživački na drukčiji način od dosadašnjih književnih, ali taj aspekt nije dovoljno naglašen da bi spasio cijelu stvar; sažeci se čine korisnijima, ali opet, ne čini mi se da postoji neki objedinjeni kriteriji za njihovo ocjenjivanje; najpraktičniji obavezni kolegij dosada, no onaj iz kojeg sam dobila najmanje [ocjenu].

$\mathrm{Na}$ posljednje, deveto, pitanje, a prikazano u Tablici 9., ispitanici su odgovorili u kojoj mjeri smatraju da je kolegij relevantan za njihove potrebe na budućem radnom mjestu. 24 studenata smatra da je kolegij izuzetno relevantan, 30 studenata da je vrlo relevantan, a 17 da je relevantan. No, 6 studenata smatra da je kolegij nedovoljno relevantan za njihove buduće poslove.

Tablica 9. U kojoj mjeri smatrate da je kolegij relevantan za vaše potrebe na budućem radnom mjestu?

\begin{tabular}{|l|l|l|l|l|}
\hline izuzetno relevantan & vrlo relevantan & relevantan & nedovoljno relevantan & nije relevantan \\
\hline $24(31 \%)$ & $30(39 \%)$ & $17(22 \%)$ & $6(8 \%)$ & - \\
\hline
\end{tabular}

Ispitanici su i obrazložili svoja stajališta, od kojih izdvajamo samo najzanimljivija. Treba napomenuti da su dodatna obrazloženja dali većinom oni ispitanici koji smatraju kolegij vrlo i izuzetno relevantnim.

- važno kako za daljnji studij, tako i za buduće radno mjesto; vjerojatno će nas se većina baviti pisanjem 
- razumijevanje teksta kao cjeline je važno za prevođenje

- mislim da svaka osoba mora znati napisati smisleni esej

- kolegij pruža mogućnost da se pomno prouči i posveti detaljnom oblikovanju teksta, što smatram izuzetno važnim

- bit će mi potrebne vještine dubinskog čitanja, analize tekstova te sposobnost sažimanja za rad u prevoditeljskom i profesorskom području

- sve profesije otvorene nakon ovog studija zahtijevaju sposobnost istraživanja i kritičkog razmišljanja koje kolegij kultivira

- vještine koje se ovdje treniraju primjenjive su i korisne za bilo koji aspekt života

- istraživački radovi su vrlo važni za nas i svakako je važno da smo ih na ovom kolegiju savladali

- budući da se planiram baviti poviješću umjetnosti, ovaj kolegij mi je bio iznimno koristan jer ću često morati pisati sažetka i znanstvene radove

- kao osoba koja bi u budućnosti htjela raditi kao sveučilišni profesor, vjerujem da će mi pisanje eseja koje sam ovdje naučio biti od velike pomoći pri pisanju znanstvenih radova u budućnosti

- želim se baviti komunikologijom i odnosima s javnošću tako da će mi čitanje s razumijevanjem biti jako potrebno

Svega je par komentara studenata koji ne smatraju ovaj kolegij dovoljno relevantnim.

- nadam se prevoditeljskom poslu nakon završetka studija pa nije toliko relevantan iako svejedno moram znati izvući značenje iz teksta kako bih ga mogao pravilno prevesti

- smatram da ovo znanje neće biti potrebno u budućnosti

Kao što je vidljivo iz prikazanih odgovora, rezultati anketa pokazuju prilično visok stupanj podudaranja naše nastavničke i studentske procjene primjerenosti sadržaja i metoda korištenih u nastavi ostvarenju ishoda kolegija te uklopljenosti kolegija u studijski program i njegove korisnosti za daljnji studij i budući rad. Naime, bez obzira jesu li studenti dali dodatna obrazloženja svojih odgovora, njihovi odgovori u brojčanome smislu ukazuju na to da ishode, sadržaje i metode poučavanja u kolegiju smatraju korisnima. Nadalje, komentari studenata koji su dodatno obrazložili svoje odgovore pokazuju da im je jasno s kojom se svrhom u kolegiju obrađuju pojedini sadržaji, da smatraju te sadržaje korisnima, a metode njihove obrade primjerenima i učinkovitima. Osim toga, studenti u najvećem dijelu razumiju kako su ishodi ovoga kolegija povezani s ishodima drugih kolegija tijekom studija te koji preduvjeti trebaju biti ostvareni da bi ishodi ovoga kolegija mogli biti uspješno savladani. Donekle iznenađuju odgovori troje studenata iz kojih jasno proizlazi da ne razumiju zašto je dobro poznavanje gramatičkih struktura, prvenstveno sintakse, nužan preduvjet za dubinsko razumijevanje i produkciju tekstova. Međutim, i takav je nalaz 
korisna informacija nama kao nastavnicima jer ukazuje na to da neke nama samorazumljive pretpostavke ne smijemo podrazumijevati, nego da trebamo eksplicitno objašnjavati studentima zašto su sve razine jezične analize preduvjet za dubinsko čitanje i razumijevanje teksta. Nadalje, u kontekstu organizacije preddiplomskoga studija i planiranja ishoda u pojedinim semestrima studija, korisna nam je informacija da jedan dio studenata smatra da bi ovakav kolegij trebali imati na samom početku studija, kao pripremu za pisanje seminarskih radova, uzevši u obzir da se tek na početku studija u pravom smislu susreću s vještinama akademskoga pisanja. Naime, jedini vođeni zadatak pisanja eseja s kojim se studenti susreću u ranijem školovanju zapravo je priprema za pisanje eseja iz engleskog i hrvatskog jezika na državnoj maturi. Međutim, ti eseji drugačije su koncipirani i ne mogu se smatrati akademskim pisanjem u pravom smislu riječi jer ne podrazumijevaju istraživački rad ni citiranje korištenih izvora. Stoga je studentska primjedba opravdana. Međutim, također je opravdan i slijed kolegija u sadašnjem studiju anglistike jer je u studiju stranoga jezika najprije nužno dosegnuti stupanj kompetencije blizak izvornom govorniku kako bi se moglo razumjeti i proizvoditi složene akademske tekstove. Konačno, posebno su zanimljiva obrazloženja studenata zašto smatraju ovaj kolegij korisnim za svoje buduće potrebe na radnom mjestu jer ta objašnjenja zorno pokazuju za koja radna mjesta studenti smatraju da će ih studij anglistike kvalificirati, na kojim bi poslovima željeli raditi te koje vještine i kompetencije smatraju bitnima za svoju buduću profesiju. To nam ukazuje da studenti itekako promišljaju o svojim budućim karijerama te procjenjuju korisnost pojedinih kolegija i studijskoga programa u cjelini za svoja buduća željena zaposlenja.

Naravno, u interpretaciji rezultata ankete svakako treba uzeti u obzir mogućnost da su anketu ispunili studenti koji su bili motivirani za rad u kolegiju i zadovoljni samim kolegijem, dok se značajan udio studenata (32 \% u prvoj i čak $87 \%$ u drugoj godini anketiranja) nije izjasnio o svojoj procjeni kolegija. Zbog reprezentativnosti rezultata bilo bi vrijedno razmisliti o tome da studentsko izjašnjavanje o kolegiju postane obavezno.

\section{ZAKLJUČAK}

U današnjem svijetu koji se ubrzano mijenja pod utjecajem novih tehnologija obrazovni sustavi ne mogu si dozvoliti da budu rigidni i tromi. Potreba za osluškivanjem promjena i anticipiranjem budućih potreba posebno je izražena u području visokoga obrazovanja, koje obrazuje stručnjake za pojedine profesije i dodjeljuje im kvalifikacije koje im omogućuju da se bave 
tim profesijama. Kad se tome doda i trend povećane mobilnost radne snage i globalizacije tržišta rada, potreba za transparentnošću i usklađivanjem visokoobrazovnih kvalifikacija postaje sve izraženija. Hrvatska kao članica Europske unije i potpisnica Bolonjske deklaracije ima obvezu kontinuirano usklađivati nacionalni visokoobrazovni sustav i nacionalni kvalifikacijski okvir s europskim, vodeći se načelima koja propisuju strateški dokumenti na razini Europske unije. Za razliku od primarnoga i sekundarnoga obrazovanja, gdje obrazovne kurikule propisuju i sastavljaju nadležne institucije, u sustavu visokoga obrazovanja pojedine studijske programe i silabe pojedinih kolegija samostalno kreiraju nastavnici koji predaju u tim kolegijima. Stoga je od presudne važnosti da nastavnici promišljaju o ishodima vlastitih kolegija i studijskih programa u kontekstu šire slike uloge visokoga obrazovanja, njegove odgovornosti prema zajednici, pojedinim dionicima društva i društvu u cjelini te ugovornih obveza koje smo kao sustav visokoga obrazovanja dužni poštivati.

U ovom smo radu na temelju primjera iz prakse, primjera kreiranja i procjene ishoda jednoga kolegija u preddiplomskom studiju anglistike, pokušali pokazati da ishodi pojedinih kolegija moraju biti osmišljeni tako da jasno doprinose ostvarenju ishoda studijskoga programa u cjelini, pri čemu je bitno procijeniti i prikladan trenutak u kojem studenti slušaju kolegij, imajući u vidu njihova predznanja pri ulasku u studij, kolegije koje su ranije slušali i kompetencije koje su u njima stekli te, u konačnici, i krajnju kvalifikaciju koju studenti stječu diplomom i njihovu buduću profesionalnu djelatnost. S obzirom da se na tržištu rada očekuju velike promjene, u promišljanju ishoda kolegija i ishoda studija potrebno je voditi računa o postizanju ravnoteže između generičkih kompetencija i specifičnih kompetencija vezanih za struku te naglasak staviti na one kompetencije za koje se procjenjuje da će biti potrebne za kvalitetan rad neovisno o neslućenim tehnološkim i organizacijskim promjenama koje će se u budućnosti dogoditi. Takve kompetencije u svakom slučaju uključuju načelne kategorije ishoda koje opisuju Dublinski deskriptori, kategorije poput kritičkoga promišljanje problema, sposobnosti prikupljanja i interpretiranja podataka te sposobnosti komuniciranja informacija i ideja. U slučaju studija anglistike temeljni jezični kolegiji poput Analize engleskih tekstova studente trebaju pripremiti za parafraziranje, sažimanje i kritičku procjenu pročitanih tekstova te za planiranje i pisanje vlastitih akademskih tekstova, vodeći računa o profesionalnim i etičkim uzusima akademskoga istraživanja. Uz nastavničku procjenu i smjernice koje propisuju strateški dokumenti, bitan element u kreiranju ishoda kolegija i procjeni njihove ostvarenosti svakako je 
i studentska procjena, koja osim što nastavnicima daje povratnu informaciju i smjernice za potrebne promjene, također aktivno uključuje studente u proces promišljanja ishoda studijskoga programa i njihove korisnosti za bavljenje profesijama za koje ih njihovi studijski programi kvalificiraju. Takav aktivni pristup u svijetu cjeloživotnoga obrazovanja postaje imperativ.

\section{LITERATURA}

Anderson, L., Krathwohl, D.A. (2001) A taxonomy for learning, teaching and assessing: A revision of Bloom's Taxonomy of educational objectives. New York: Longman.

Biggs, J., Tang, C., (2007) Teaching for quality learning at university. SRHE i Open University Press, Maidenhead.

Bolonjski proces. https://www.azvo.hr/hr/visoko-obrazovanje/bolonjski-proces, pristupljeno 15. 1. 2021. Kvalifikacijski okvir za europski prostor visokog obrazovanja. Bologna Working Group (2005) A Framework for Qualifications of the European Higher Education Area. Bologna Working Group Report on Qualifications Frameworks (Copenhagen, Danish Ministry of Science, Technology and Innovation)

Dublinski deskriptori. Bologna Follow-Up Group (2005) Framework for Qualifications of the European Higher Education Area. Kopenhagen, str. 9.

Hrvatski kvalifikacijski okvir, www.kvalifikacije.hr, pristupljeno 15. 1. 2021.

Kolić-Vehovec, S. (2013) Kognitivni i metakognitivni aspekti čitanja. U Mićanić, M. (ur.) Čitanje za školu i život. Zagreb: Agencija za odgoj i obrazovanje, str. 23-32.

Leuven Communiqué (2009) (Leuven_Louvain-la-Neuve_Communique_April2009.doc (ehea.info), pristupljeno 25 .4. 2021.

London Communiqué (2007) (2007_London_Communique_English_588697.pdf (ehea.info), pristupljeno 25. 4. 2021.

Peti-Stantić, A. (2019) Čitanjem do spo(razumijevanja). Od čitalačke pismenost do čitateljske sposobnosti. Zagreb: Ljevak.

Standards and Guidelines for Quality Assurance in the European Higher Education Area (ESG_2015.pdf (enqa.eu))

Tuning (2008) Universities' contribution to the Bologna process - an introduction. http:// www.unideusto.org/tuningeu/images/stories/Publications/ENGLISH_BROCHURE_ FOR_WEBSITE.pdf

Vlahović-Štetić, V., Kamenov, Ž. (2016) Kako ostvariti željene ishode u studijskim programima? Priručnik za sveučilišne nastavnike, Zagreb: FF press.

http://esfhko.ffzg.unizg.hr/wp-content/uploads/2016/08/Prirucnik-EU-FF_web_final.pdf ZEROJ. Vijeće Europe (2005) Zajednički europski referentni okvir za jezike: učenje, poučavanje, vrednovanje. Zagreb: Školska knjiga. 


\title{
Teacher and student perspectives in designing and (re-)evaluating the outcomes and content of the course Analysis of English Texts
}

\author{
Ivana Bašić \\ ibasicmobile@gmail.com \\ Faculty of Humanities and Social Sciences, University of Zagreb \\ Marina Zubak Pivarski \\ marina.zubak.pivarski@gmail.com \\ Faculty of Humanities and Social Sciences, University of Zagreb
}

\begin{abstract}
This paper addresses the issues of the design and (re-)evaluation of the outcomes and content of the course named Analysis of English Texts, an obligatory course in the undergraduate program in English language and literature at the Faculty of Humanities and Social Sciences, University of Zagreb. The discussion is set in the wider context of designing university course outcomes in accordance with contemporary higher education strategic goals as well as contemporary approaches to teaching and learning. The first part of the paper provides a detailed analysis of the teacher perspective in the process of defining the learning outcomes of the course, as well as its content, structure, and teaching methods, while the second part presents the results of a survey conducted among students upon completion of the course with the aim of getting feedback on the students' perception of the completion of the outcomes, appropriateness of the course content and methods of teaching, as well as the usefulness of the course in the context of the study program and their future professional needs. The conclusion of the paper is that course outcomes design needs to be informed by the following criteria: contribution of the course to the general outcomes of the study program, contribution of the course outcomes to the students' future work in the profession(s) that the study program prepares them for, and finally, alignment with the principles and guidelines proposed by the strategic documents that govern the higher education systems in the Republic of Croatia and the European Union. Furthermore, it is essential that students be actively engaged in the process of course design and evaluation, as their assessment both provides valuable feedback to educators and enables students to raise their own awareness as to the objectives of their education and the competences necessary for their future professional work.
\end{abstract}

Key words: competence approach to higher education, teacher and student perspective in (re-) evaluating courses, generic and specific competences in the English undergraduate program 